\title{
Size, productivity, and international banking
}

Buch, Claudia M ; Koch, Cathérine T ; Koetter, Michael

\begin{abstract}
Heterogeneity in size and productivity is central to models that explain which manufacturing firms export. This study presents descriptive evidence on similar heterogeneity among international banks as financial services providers. A novel and detailed bank-level data set reveals the volume and mode of international activities for all German banks. Only a few, large banks have a commercial presence abroad, consistent with the size pecking order documented for manufacturing firms. However, the relationship between internationalization and productivity also yields two inconsistencies with recent trade models. First, virtually all banks hold at least some foreign assets, irrespective of size or productivity. Second, some fairly unproductive banks maintain commercial presences abroad.
\end{abstract}

DOI: https://doi.org/10.1016/j.jinteco.2011.07.001

Posted at the Zurich Open Repository and Archive, University of Zurich

ZORA URL: https://doi.org/10.5167/uzh-54289

Journal Article

Published Version

Originally published at:

Buch, Claudia M; Koch, Cathérine T; Koetter, Michael (2011). Size, productivity, and international banking. Journal of International Economics, 85(2):329-334.

DOI: https://doi.org/10.1016/j.jinteco.2011.07.001 


\title{
Size, productivity, and international banking
}

\author{
Claudia M. Buch a,b,*, Cathérine T. Koch ${ }^{\text {c }}$, Michael Koetter ${ }^{\text {d,e }}$ \\ a University of Tuebingen, Faculty of Economics and Social Sciences, Mohlstrasse 36, 72074 Tuebingen, Germany \\ ${ }^{\mathrm{b}}$ IAW, Ob dem Himmelreich 1, 72074 Tuebingen, Germany \\ c University of Zurich, Department of Economics, Zuerichbergstrasse 14, 8032 Zurich, Switzerland \\ ${ }^{\mathrm{d}}$ University of Groningen E' CIBIF, Faculty of Economics and Business, PO Box 800, 9700 AV Groningen, The Netherlands \\ e Sveriges Riksbank, Research Division, 10337 Stockholm, Sweden
}

\section{A R T I C L E I N F O}

\section{Article history:}

Received 16 September 2009

Received in revised form 1 June 2011

Accepted 2 July 2011

Available online 14 July 2011

JEL classifications:

F3

G21

Keywords:

Trade in financial services

International banking

Foreign entry modes

Size

Productivity

\begin{abstract}
A B S T R A C T
Heterogeneity in size and productivity is central to models that explain which manufacturing firms export. This study presents descriptive evidence on similar heterogeneity among international banks as financial services providers. A novel and detailed bank-level data set reveals the volume and mode of international activities for all German banks. Only a few, large banks have a commercial presence abroad, consistent with the size pecking order documented for manufacturing firms. However, the relationship between internationalization and productivity also yields two inconsistencies with recent trade models. First, virtually all banks hold at least some foreign assets, irrespective of size or productivity. Second, some fairly unproductive banks maintain commercial presences abroad.
\end{abstract}

(c) 2011 Elsevier B.V. All rights reserved.

\section{Motivation}

To present descriptive evidence on the relationship between size, productivity, and the internationalization patterns of banks, we use a novel micro data set: the External Position Report (Auslandsstatus) provided by the German central bank, the Deutsche Bundesbank. Using data that cover all 2226 German banks' international exposures in 63 countries during the years 2002-2006, we explore a potentially important new data source for research in international trade in financial services. We ask if observed internationalization patterns of banks are consistent with the evidence previously presented for manufacturing firms.

In manufacturing, larger and more productive firms are more likely to export and engage in foreign direct investment (FDI) than are smaller and less productive firms (Eaton et al., 2004; Helpman et al., 2004; Bernard et al., 2007; Lileeva and Trefler, 2010), due to the interaction between firm-level productivity and the costs of market entry (Melitz, 2003; Helpman et al., 2008): domestic fixed costs are lower than the fixed costs of exporting, which are lower than the fixed costs of FDI. ${ }^{1}$ Firms self-select into different modes of entry, because

\footnotetext{
* Corresponding author at: University of Tuebingen, Faculty of Economics and Social Sciences, Mohlstrasse 36, 72074 Tuebingen, Germany. Tel.: + 497071 2972962; fax +497071295071.

E-mail addresses: claudia.buch@uni-tuebingen.de (C.M. Buch),

catherine.koch@iew.uzh.ch (C.T. Koch), m.koetter@rug.nl (M. Koetter).

${ }^{1}$ This disadvantage of FDI is compensated for by the lower variable costs for FDI firms.
}

the higher fixed costs of more complex foreign activity modes require higher productivity, which results in a "pecking order of productivity". We distinguish the cross-border provision of financial services and commercial presences (branches or subsidiaries) as modes.

We advance this literature field in three ways. First, the External Position Report is a census without a reporting threshold, which mitigates the sample selection concerns in previous international banking studies (e.g. Buch and Lipponer, 2007). German banks are heterogeneous in terms of their size, ranging from mean customer lending of $€ 36$ million in the bottom quartile to a mean of $€ 4.4$ billion in the largest quartile of banks. We therefore analyze the implications of this size heterogeneity for bank internationalization.

Second, we shed light on similarities and differences between manufacturing and services firms' internationalization. Most prior empirical evidence pertains to manufacturing firms, despite the growing importance of trade in services, ${ }^{2}$ and the few studies of services are theoretical, focus on post-production services, or analyze the liberalization of trade (Konan and Maskus, 2006; Wong et al., 2006; Ishikawa et al., 2010). Yet unlike manufacturing firms, virtually

\footnotetext{
2 Between 2000 and 2008, worldwide trade in commercial services grew by $14 \%$. In 2008 , the ratio of commercial services exports to gross domestic product was $4 \%$ in the EU, compared with $10 \%$ for manufacturing exports (WTO, 2009). Outward FDI by financial services providers accounts for $61 \%, 22 \%$, and $29 \%$ of total FDI in services in the EU 27, Germany, and the United States, respectively. Exports of financial services account for $9 \%, 5 \%$, and $12 \%$ of total services exports for these countries.
} 
all banks (96\%) are active internationally. Similar to evidence in manufacturing though, we find that very few banks have commercial presences abroad in the form of branches (1.2\%) or subsidiaries (1.7\%). Larger banks also maintain larger foreign exposures, are active in more countries, and appear in countries located farther away from Germany.

Third, for each bank, we can distinguish trade in financial services from FDI. Rather than studying the choice between exports (or FDI) separately, we investigate whether banks' foreign entry modes correlate with either size or productivity. Consistent with evidence for manufacturing firms (see e.g. Mayer and Ottaviano, 2007), we find a size-based pecking order across modes of internationalization. However, some unproductive banks also operate within the most complex internationalization modes and maintain affiliates abroad.

We do not address issues of causality. For manufacturing firms, van Biesebroeck (2005) and De Loecker (2007) show that exports may in fact increase productivity. Lileeva and Trefler (2010) also demonstrate that size and productivity are not perfectly correlated across firms. If firms' investment in productivity is endogenized, then even less productive firms may export. Here, we limit our efforts to distinguish three increasingly complex (fixed-cost intensive) modes of foreign entry and presenting descriptive evidence of the extent to which this categorization correlates with bank size and productivity.

\section{Data}

\subsection{External Position Report}

The External Position Report (Auslandsstatus) of the Deutsche Bundesbank reports the international assets of 2226 German banks, their foreign branches, and their foreign subsidiaries for 63 countries. ${ }^{3}$ Because we are interested in the longer-run patterns of bank internationalization, the sample covers 2002-2006, that is, after reporting thresholds were abolished in January 2002 but prior to the recent global financial crisis. We have exact information about both the extensive margin (whether a bank is active abroad) and the intensive margin (volume of international activity). We match branches and subsidiaries located in country $j$ with their domestic parent bank $i$. The intensive margin is the sum of all assets held in country $j$ per mode. Assets held by affiliates can be attributed to their respective host countries. We consider total foreign assets, ${ }^{4}$ and we measure size and productivity using data on banks' domestic activities that are contained in the financial statements regularly reported to the Deutsche Bundesbank.

Entry into and exit from foreign markets is sparse in this sample, ${ }^{5}$ so we focus on cross-sectional heterogeneity in German banking, collapse the data along country and time dimensions, and analyze the average internationalization patterns of German banks.

\footnotetext{
${ }^{3}$ See Fiorentino et al. (2010) for a technical description. We sampled the following 63 countries that account for approximately 90\% of total foreign assets of German banks: Argentina, Austria, Australia, Belgium, Bulgaria, Brazil, Canada, Chile, China, Colombia, Côte D'Ivoire, Cyprus, the Czech Republic, Denmark, Estonia, Egypt, Spain, Finland, France, Greece, Hong Kong, Hungary, Indonesia, Ireland, Israel, India, Italy, Japan, Jordan, South Korea, Latvia, Lithuania, Luxemburg, Malaysia, Malta, Mauritius, Mexico, Morocco, the Netherlands, Norway, New Zealand, Pakistan, Panama, Peru, the Philippines, Poland, Portugal, Romania, Russia, Saudi Arabia, Singapore, Slovakia, South Africa, Sri Lanka, Sweden, Switzerland, Thailand, Turkey, Ukraine, the United Kingdom, the United States, Uruguay, and Vietnam.

${ }^{4}$ Foreign assets include loans and advances to banks, companies, and governments, bonds and notes, foreign shares and other equity stakes abroad, denominated or converted into euro. The largest asset class is loans.

${ }^{5}$ Of the 2226 banks active during 2002-2006, only 15 changed their internationalization mode at least once, such as from cross-border lending to foreign branches. These banks tend to be among the lower ranks of the largest 100 banks. All three banking sectors in Germany (commercial, savings, and cooperative banks) are represented. They exhibit no particular pattern in terms of productivity, size, or other performance indicators that we considered.
}

\subsection{International activity modes}

We distinguish four modes of banking activities, ranked by the fixed costs of operating abroad. The first mode is domestic. Only 19 banks (less than $1 \%$ of the population) report no foreign assets in any of the years or countries.

The second mode, cross-border, includes banks with international assets in at least one country held by the domestic headquarters. These banks provide financial services to foreign counterparties and are analogous to exporters in manufacturing. Estimating the value of banking services is difficult, because prices are often unobservable (Basu et al., 2008). In line with prior banking literature, we assume that international assets, which earn interest and fees, embody the value of financial services and represent bank output (see e.g. Koetter et al., Forthcoming). The vast majority of banks in our sample (2143 banks, 96\%) fall into this cross-border mode, which may reflect our categorization, which is based on the ownership of any foreign asset, including financial assets such as U.S. Treasury bills. Alternatively, when we classify banks on the basis of international lending to households and corporations alone, the share of banks classified as purely domestic increases from less than $1 \%$ to $11 \%$. This number is still lower than in typical datasets for manufacturing firms. The majority of foreign assets reflect cross-border lending, which requires costly screening and monitoring.

The third and fourth modes distinguish two different types of commercial presence, namely, foreign branches and subsidiaries. Only 27 banks maintain foreign branches but no subsidiaries; 37 banks run foreign subsidiaries and/or foreign branches (10 of which maintain foreign subsidiaries but no foreign branches). The decision to rank the subsidiary mode higher than foreign branches is inevitably heuristic to some extent. Our choice is based on interviews with Bundesbank officials and reflects regulatory incentives: operating legally independent subsidiaries abroad involves higher fixed costs, in terms of capital and regulatory requirements (Cerutti et al., 2007), yet the variable costs of lending are lower, because knowledge of local markets can reduce screening costs and facilitate client relationships (Degryse and Ongena, 2005).

\section{Size heterogeneity, complexity, and international banking}

We illustrate in Table 1 the size heterogeneity in German banking and the link with different activity modes. We classify banks according to modes of foreign activity, and size classes are based on the domestic customer lending and total asset distribution.

Horizontally, Table 1 indicates the four blocks of increasingly complex foreign activities: domestic, cross-border, branches, and subsidiaries. For each mode, we show the cumulative distribution of banks, such that the number of banks increases. The size thresholds correspond to the 25th, 50th, and 75th percentile of the customer lending (total assets) distribution. The value of the first threshold value is $€ 67$ million ( $€ 125$ million). Size classes to the right contain banks that lend to customers up and until the 50th percentile, which equals $€ 191$ million ( $€ 330$ million). The 75th percentile of the customer lending distribution is $€ 506$ million ( $€ 916$ million) and we also include the 100th percentile, which equals $€ 366$ billion ( $€ 1,036$ billion), to show the skewness of the size distribution of German banks. Vertically, Table 1 consists of two panels that show how many banks are active abroad and the complexity of their foreign operations.

\subsection{How many banks are active abroad?}

Panel A in Table 1 shows that the size distribution of banks is highly skewed. Mean lending of banks in the top quartile equals $€ 4.4$ billion as opposed to average loans of $€ 36$ million for banks in the bottom quartile (not shown). For each mode, we show the number of 
Table 1

Cumulative size distributions and international activities of German banks.

\begin{tabular}{|c|c|c|c|c|c|c|c|c|c|c|c|c|c|c|c|c|}
\hline \multirow[b]{2}{*}{ Mode } & (1) & $(2)$ & (3) & $(4)$ & $(5)$ & $(6)$ & $(7)$ & $(8)$ & (9) & $(10)$ & $(11)$ & $(12)$ & (13) & $(14)$ & $(15)$ & $(16)$ \\
\hline & \multicolumn{4}{|c|}{ Domestic } & \multicolumn{4}{|c|}{ Cross-border } & \multicolumn{4}{|l|}{ Branches } & \multicolumn{4}{|c|}{ Subsidiaries } \\
\hline Size class (percentile) & 25 th & 50 th & 75th & 100th & 25 th & 50 th & 75 th & 100th & 25 th & 50th & 75th & 100th & 25 th & 50th & 75th & 100th \\
\hline Banks: 2226 (total) & 557 & 1113 & 1670 & 2226 & 557 & 1113 & 1670 & 2226 & 557 & 1113 & 1670 & 2226 & 557 & 1113 & 1670 & 2226 \\
\hline \multicolumn{17}{|c|}{ Panel A: Participation frequency } \\
\hline \multicolumn{17}{|l|}{ Number of banks } \\
\hline Customer lending & 16 & 18 & 19 & 19 & 538 & 1087 & 1638 & 2143 & 3 & 6 & 10 & 27 & 0 & 2 & 3 & 37 \\
\hline Gross total assets & 17 & 18 & 19 & 19 & 539 & 1091 & 1638 & 2143 & 1 & 4 & 11 & 27 & 0 & 0 & 2 & 37 \\
\hline \multicolumn{17}{|l|}{ Share in total (\%) } \\
\hline Customer lending & $0.7 \%$ & $0.8 \%$ & $0.9 \%$ & $0.9 \%$ & $24.2 \%$ & $48.8 \%$ & $73.6 \%$ & $96.3 \%$ & $0.1 \%$ & $0.3 \%$ & $0.4 \%$ & $1.2 \%$ & $0 \%$ & $0.1 \%$ & $0.1 \%$ & $1.7 \%$ \\
\hline Gross total assets & $0.8 \%$ & $0.8 \%$ & $0.9 \%$ & $0.9 \%$ & $24.2 \%$ & $49.0 \%$ & $73.6 \%$ & $96.3 \%$ & $0.0 \%$ & $0.2 \%$ & $0.5 \%$ & $1.2 \%$ & $0 \%$ & $0 \%$ & $0.1 \%$ & $1.7 \%$ \\
\hline \multicolumn{17}{|c|}{ Panel B: Internationalization traits } \\
\hline \multicolumn{17}{|c|}{ Number of countries } \\
\hline Cross-border & & & & & 7.2 & 9.4 & 11.4 & 14.1 & 9.3 & 10.8 & 14.4 & 27.8 & & 19.5 & 25.7 & 40.3 \\
\hline Branches & & & & & & & & & 1.0 & 1.3 & 1.3 & 1.4 & & & & 5.3 \\
\hline Subsidiaries & & & & & & & & & & & & & & 1.0 & 1.3 & 3.1 \\
\hline \multicolumn{17}{|l|}{ Mean distance (km) } \\
\hline Cross-border & & & & & 2454 & 2398 & 2415 & 2554 & 2609 & 2281 & 2517 & 3426 & & 2633 & 3389 & 4440 \\
\hline Branches & & & & & & & & & 916 & 714 & 685 & 1294 & & & & 3243 \\
\hline Subsidiaries & & & & & & & & & & & & & & 635 & 627 & 1273 \\
\hline \multicolumn{17}{|l|}{ Intensive margin ( $€ \mathrm{~m})$} \\
\hline Cross-border & & & & & 6 & 13 & 38 & 70 & 29 & 51 & 337 & 3335 & & 82 & 150 & 25,006 \\
\hline Branches & & & & & & & & & 16 & 20 & 18 & 2160 & & & & 26,154 \\
\hline Subsidiaries & & & & & & & & & & & & & & 134 & 137 & 7434 \\
\hline
\end{tabular}

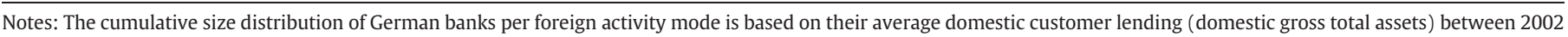

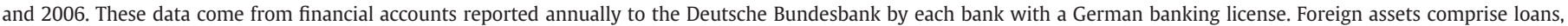

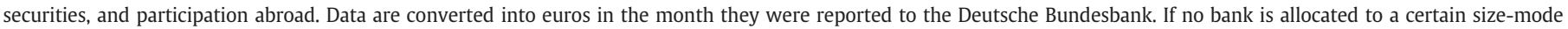

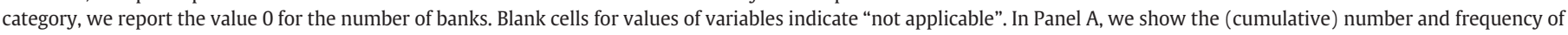

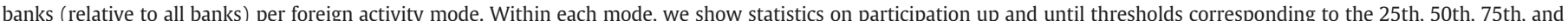

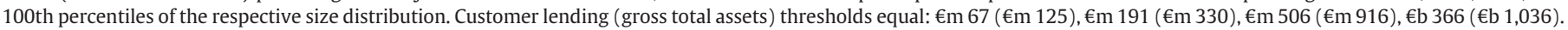

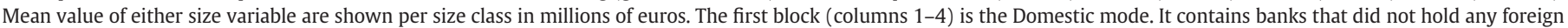

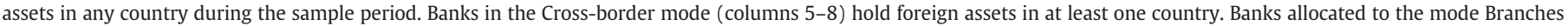

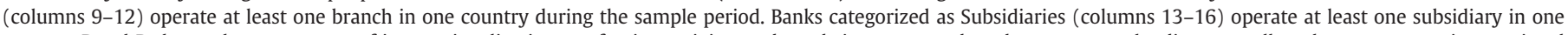

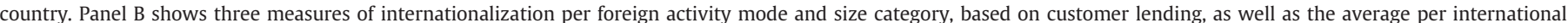

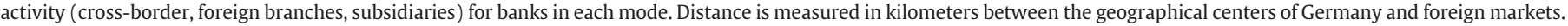
The number of countries is a count of foreign markets. The intensive margin is the mean exposure per international activity in millions of euro.

banks per size group and the share relative to the total number of banks. As in manufacturing, the largest banks maintain commercial presences abroad. Up to the 75th percentile, only 10 banks have foreign branches and only 3 banks have foreign subsidiaries (Columns 11 and 15). But 538 of the 557 smallest banks hold cross-border assets (Column 5), and 3 small banks even operate foreign branches (Column 9). Only a tiny fraction of all banks $(0.9 \%$, Column 4$)$ is strictly domestic. In manufacturing in contrast, many firms do not export at all and thus would fall into the domestic mode (see e.g. Eaton et al., 2004). The low share of purely domestic banks corroborates the anecdotal evidence that the financial industry is very globalized and internationally connected. ${ }^{6}$

\subsection{How complex are banks' international activities?}

Panel B describes the international activities of banks in terms of the complexity of foreign operations. We distinguish the number of countries, the mean distance to foreign markets, and the volume of banks' international activities.

Larger banks are active in more countries. For the full sample, banks with cross-border activities only are active in 14 countries on average (Column 8). Banks with foreign branches operate on average in fewer than 2 countries (Column 12), but their cross-border assets

\footnotetext{
${ }^{6}$ Size classes are based on customer lending. The results are identical for total assets and other size indicators. We also classified banks on the basis of typical bank performance measures: Lerner indices (see Section 4.2), non-performing loan ratio, and labor productivity. The qualitative results are largely unchanged and available on request.
}

span 28 countries. Similarly, banks with foreign subsidiaries (Column 16) hold them on average in 3 countries but have cross-border assets in approximately 40 countries. Thus, when banks enter more complex international activity modes, their cross-border lending also spans a wider range of countries. But size is less important for the international diversification of assets across countries: even the smallest banks hold foreign assets in, on average, 7 countries (Column 5 ), and $77 \%$ of all cross-border banks are active in 10 or more countries (not shown). In contrast, the geographical reach of manufacturing firms tends to be much smaller. For instance, most French exporters are active in only one foreign market, and only about $20 \%$ of exporters are active in at least 10 countries (Eaton et al., 2004).

Larger banks are active in more distant markets. The average distance to countries in which banks with cross-border assets are active is $2554 \mathrm{~km}$ (Column 8). Again though, even the smallest German banks do not just extend loans to neighboring countries but also retain financial assets outside the EU. Banks with foreign branches increase their mean cross-border reach to $3426 \mathrm{~km}$, and banks with subsidiaries span to $4440 \mathrm{~km}$. The average distance to the host country for the foreign affiliates is consistently lower than that for cross-border activities. This distance could indicate that affiliates serve as export platforms to more distant foreign markets. Banking studies also stress the positive relationship between geographical distance and information cost (Degryse and Ongena, 2005). Thus, affiliates may enhance knowledge of local markets and borrowers.

Finally, larger banks have higher foreign exposures. The mean foreign assets of the smallest banks in the cross-border mode are €6 million (Column 5) but increase more than tenfold to $€ 70$ million when we include the largest banks (Column 8). That is, many small 
Table 2

Relationship between size and international activity.

\begin{tabular}{|c|c|c|c|c|c|c|}
\hline \multirow{4}{*}{ Foreign mode } & \multirow{4}{*}{$\begin{array}{l}\text { Variable } \\
\text { Range (€m) }\end{array}$} & $(1)$ & $(2)$ & \multirow{4}{*}{$\begin{array}{l}\frac{(3)}{} \\
\frac{\text { III }}{190.7-503.3}\end{array}$} & \multirow{4}{*}{$\begin{array}{l}\frac{(4)}{\mathrm{IV}} \\
\frac{505.8-365,992}{}\end{array}$} & \multirow{4}{*}{$\begin{array}{l}(5) \\
\text { Total }\end{array}$} \\
\hline & & \multicolumn{2}{|c|}{ Size class (customer lending) } & & & \\
\hline & & \multirow{2}{*}{$\overline{\mathrm{I}} \overline{0.04-66.8}$} & \multirow{2}{*}{$\frac{\mathrm{II}}{66.8-190.6}$} & & & \\
\hline & & & & & & \\
\hline \multirow[t]{5}{*}{ Domestic } & Number of banks & 16 & 2 & 1 & 0 & 19 \\
\hline & Total assets & 26.3 & 122.3 & 482.3 & & 60.4 \\
\hline & Equity & 3.4 & 11.3 & 172.0 & & 13.1 \\
\hline & Interbank lending & 5.4 & 26.0 & 0.0 & & 7.3 \\
\hline & Borrowed funds & 21.4 & 109.7 & 290.9 & & 44.8 \\
\hline \multirow[t]{5}{*}{ Cross-border } & Number of banks & 537 & 550 & 550 & 506 & 2143 \\
\hline & Total assets & 83.5 & 227.3 & 632.7 & 3039.9 & 959.4 \\
\hline & Equity & 6.2 & 13.5 & 31.8 & 47.9 & 47.9 \\
\hline & Interbank lending & 22.7 & 39.6 & 115.7 & 396.2 & 139.1 \\
\hline & Borrowed funds & 73.1 & 203.8 & 574.5 & 2766.5 & 871.3 \\
\hline \multirow[t]{5}{*}{ Branches } & Number of banks & 3 & 3 & 4 & 17 & 27 \\
\hline & Total assets & 130.0 & 320.6 & 1452.4 & $30,144.7$ & $19,245.3$ \\
\hline & Equity & 19.2 & 34.2 & 93.8 & 985.9 & 640.6 \\
\hline & Interbank lending & 25.9 & 100.4 & 950.0 & $11,408.2$ & 7337.7 \\
\hline & Borrowed funds & 105.0 & 277.2 & 1320.5 & $27,799.2$ & $17,741.3$ \\
\hline \multirow[t]{5}{*}{ Subsidiaries } & Number of banks & 0 & 2 & 1 & 34 & 37 \\
\hline & Total assets & & 551.5 & 2206.8 & $112,161.1$ & $103,156.4$ \\
\hline & Equity & & 43.7 & 124.9 & 3029.5 & 2789.6 \\
\hline & Interbank lending & & 209.4 & 410.8 & $29,593.9$ & $27,216.9$ \\
\hline & Borrowed funds & & 378.1 & 2011.5 & $96,705.9$ & $88,939.7$ \\
\hline
\end{tabular}

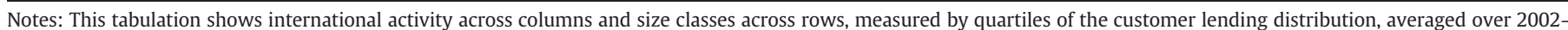

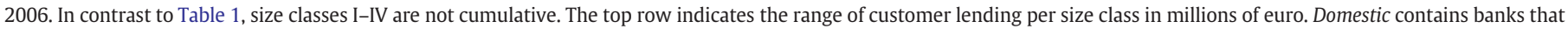

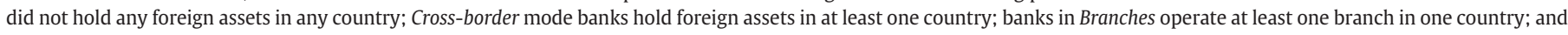

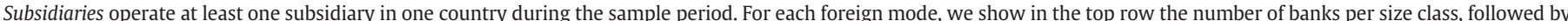

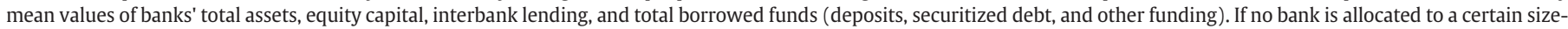
mode category, we report the value 0 for the number of banks. Blank cells for values of variables indicate "not applicable". All variables are measured in millions of euro.

banks are active abroad, but the aggregate volume of cross-border banking is dominated by a very few, large players.

Overall, these results are consistent with models of multinational firms which predict that larger banks should be more active in international markets in terms of their volume (intensive margin), number of countries (extensive margin), and complexity of foreign activities.

\section{Size and productivity in international banking}

\subsection{Size and internationalization}

With Table 2, we inspect more closely whether the internationalization of German banks resembles a pecking order in terms of size. Accordingly, we sort the banks into mutually exclusive size quartiles, based on domestic customer lending. ${ }^{7}$ The column headers show the range of each classification in millions of euro.

Across rows, we also classify banks by their mode of international activity. In each quartile-mode cell, we report the number of banks and the mean value of four alternative size variables that measure the scale of banks' total activities beyond their core lending business (total assets), degree of capitalization (equity), degree of connectedness with other banks (interbank lending), and importance of deposit funding (borrowed funds).

The design of Table 2 highlights two main features of the data. First, for the full sample (Column 5), banks in more complex modes are larger, consistent with Melitz-type models of heterogeneous firms in which larger firms are more productive. Yet virtually all banks hold cross-border assets, and even a few banks in the two smallest size classes have affiliates. Both these observations are inconsistent with models of heterogeneous firms in which size and productivity are

\footnotetext{
${ }^{7}$ A size categorization based on full-time equivalent employees yielded similar results.
}

related monotonically. Second, within the individual size groups (Columns 1 to 4 ), the mean size of banks generally increases with the complexity of foreign modes, which is consistent with Melitz-type of models. The more complex the foreign mode, the larger the banks across all dimensions we considered. Most banks that pursue complex internationalization strategies belong to the largest size quartile. The only two exceptions to this pattern are in size class III, but refer to groups with one bank only and are thus hard to interpret. ${ }^{8}$

\subsection{Productivity and internationalization}

According to Melitz (2003), productivity is the main (exogenous) source of heterogeneity across firms, and it is perfectly correlated with size. However, as we shall see in our data, productivity and size are not perfectly correlated and a few small, unproductive banks have foreign branches and subsidiaries. This is consistent with a similar observation made by Lileeva and Trefler (2010), who find (a) a weak correlation between productivity and size in Canadian manufacturing firms and (b) small, unproductive exporters. They provide a theoretical and empirical explanation that appeals to the fact that small export starters are investing in raising their productivity.

We investigate the relationship among productivity, size, and international activities of German banks in Table 3. Across the columns, we allocate banks to productivity quartiles on the basis of two measures, labor productivity and Lerner indices as defined in Section 4.2 below. Across the rows, we distinguish internationalization modes. In each cell, we show the mean bank size. ${ }^{9}$

The top panel in Table 3 classifies banks according to their labor productivity (total assets/full-time equivalent employees), which

\footnotetext{
${ }^{8}$ Equity in the Domestic mode of size class III is larger than that in more complex modes and interbank lending in the most complex Subsidiary mode is lower compared to the Branches mode.

${ }^{9}$ We measure size as domestic customer lending; measures using total assets, equity, or borrowed funds are qualitatively identical.
} 
Table 3

Relationship between bank productivity and international activity.

\begin{tabular}{|c|c|c|c|c|c|c|}
\hline & & $(1)$ & $(2)$ & (3) & $(4)$ & (5) \\
\hline \multicolumn{7}{|c|}{ Labor productivity } \\
\hline \multirow[b]{2}{*}{ Foreign mode } & \multirow[b]{2}{*}{ Range ( $€ \mathrm{~m}$ per FTE) } & I & II & III & IV & \multirow[t]{2}{*}{ Total } \\
\hline & & $0.18-3.32$ & $3.32-3.81$ & $3.81-4.45$ & $4.46-169.3$ & \\
\hline \multirow[t]{2}{*}{ Domestic } & Customer lending & 20.2 & & 13.9 & 126.6 & 47.2 \\
\hline & Number of banks & 11 & 0 & 3 & 5 & 19 \\
\hline \multirow[t]{2}{*}{ Cross-border } & Customer lending & 142.6 & 297.7 & 517.0 & 1290.6 & 548.7 \\
\hline & Number of banks & 536 & 553 & 550 & 504 & 2143 \\
\hline \multirow[t]{2}{*}{ Branches } & Customer lending & 455.5 & 2427.4 & 141.4 & $13,013.7$ & 7247.7 \\
\hline & Number of banks & 8 & 4 & 1 & 14 & 27 \\
\hline \multirow[t]{2}{*}{ Subsidiaries } & Customer lending & 160.4 & & 1991.4 & $39,338.6$ & 36,261 \\
\hline & Number of banks & 1 & 0 & 2 & 34 & 37 \\
\hline \multicolumn{7}{|l|}{ Lerner indices } \\
\hline & & I & II & III & IV & Total \\
\hline Foreign mode & Range (points) & $-65.6-22.9$ & $22.9-26.4$ & $26.4-29.7$ & $29.7-59.0$ & \\
\hline \multirow[t]{2}{*}{ Domestic } & Customer lending & 12.9 & 14.1 & 9.7 & 79.0 & 47.2 \\
\hline & Number of banks & 5 & 1 & 3 & 10 & 19 \\
\hline \multirow[t]{2}{*}{ Cross-border } & Customer lending & 308.2 & 378.6 & 667.6 & 810.9 & 548.7 \\
\hline & Number of banks & 519 & 525 & 517 & 582 & 2143 \\
\hline \multirow[t]{2}{*}{ Branches } & Customer lending & 721.5 & 2085.7 & $24,582.9$ & 2789.1 & 7247.7 \\
\hline & Number of banks & 4 & 3 & 6 & 14 & 27 \\
\hline \multirow[t]{2}{*}{ Subsidiaries } & Customer lending & 60,071 & $37,655.5$ & 9984.9 & $38,405.8$ & 36,261 \\
\hline & Number of banks & 3 & 3 & 5 & 26 & 37 \\
\hline
\end{tabular}

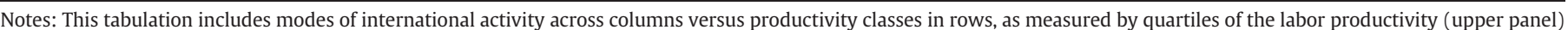

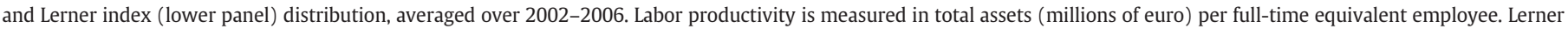

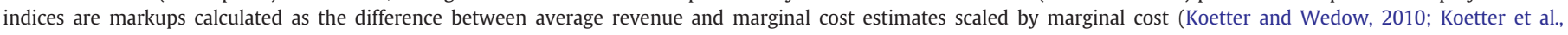

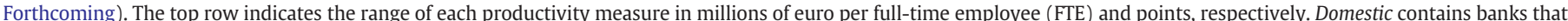

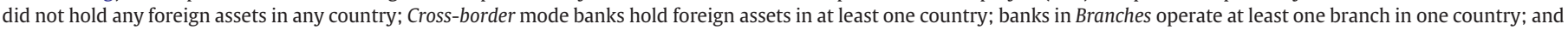

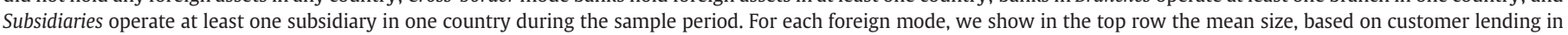

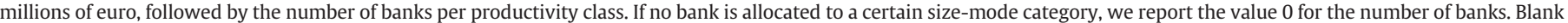
cells for values of variables indicate "not applicable".

exhibits a skewed distribution similar to that observed for size. For the majority of German banks in the cross-border category, the results are consistent with a productivity pecking order: Mean size increases monotonically across productivity quartiles. Likewise, within most productivity classes, larger banks are active in increasingly complex modes, except for those cells with very few observations.

However, some very productive banks are not abroad at all, and some unproductive banks even have foreign affiliates. Of the 27 banks in the foreign branch mode, 8 fall in the bottom quartile of the productivity distribution, and 4 are in the next lowest rank. This result is inconsistent with a simple productivity pecking order. Models of international banking therefore should account for additional sources of heterogeneity across banks.

Alternatively, labor productivity may just be a poor measure of bank productivity (Basu et al., 2008). Therefore, we calculate Lerner indices as bank-level markups between the average revenues and marginal cost (Koetter et al., Forthcoming). ${ }^{10}$ We estimate average revenues and marginal costs with latent stochastic frontier models as in Koetter and Wedow (2010). We do not aim to distinguish how much of the Lerner markup is due to superior productivity (lower marginal cost) and how much results from market power (higher average revenues) (see e.g. Martin, 2008; Chen et al., 2009). Instead, we use the Lerner markups as an alternative driver of bank internationalization, given the lack of consensus about how to measure bank productivity (Epifaniy and Ganciaz, 2010).

The bottom panel in Table 3 mimics the pattern exhibited by labor productivity. For cross-border banks, mean size increases continuously

\footnotetext{
10 See Epifaniy and Ganciaz (2010) for theory and evidence on heterogeneous markups in manufacturing and the relationship with international trade.
}

in Lerner indices. But inconsistencies from a productivity pecking order based on labor productivity also emerge. First, around 70\% of the 19 strictly domestic banks fall into the two highest Lerner index quartiles. Second, 7 (6) banks of the 27 (37) that operate foreign branches (subsidiaries) appear in the bottom two quartiles of the Lerner index distribution. In particular, banks in the subsidiary mode that exhibit very low margins are fairly large.

In unreported statistics, we also explored alternative measures of bank performance. Only a Levinsohn and Petrin (2003) productivity measures yields a pecking order across size classes and modes. However, many unprofitable (low return on equity) and risky (high non-performing loan share, low capitalization) banks are active abroad, especially in complex branch and subsidiary modes. These patterns may indicate that a bank's choice between subsidiaries and branches also results from regulatory factors and other sources of heterogeneity.

\section{Summary of findings}

We present descriptive evidence of the relationship among size, productivity, and internationalization activities by banks. In addition, we use a detailed, bank-level data set that contains detailed information about the volume and presence of all German banks in 63 foreign markets between 2002 and 2006.

Many of our observations of international banking activities are consistent with Melitz-type models of heterogeneous firms. The size and productivity distributions are dispersed and skewed, and this heterogeneity is mirrored in banks' internationalization patterns. The few banks that maintain foreign branches or subsidiaries tend to be very large; these larger banks also have increasingly complex exposures 
in terms of number of countries, distance to foreign markets, and volumes. Among the group of banks that conduct cross-border activities but do not maintain commercial presences abroad, more productive banks are also larger.

We find two important departures from a clear productivity pecking order, however. First, in contrast with typical findings for manufacturing firms, virtually all banks hold at least some foreign assets. Even the smallest banks are active in a relatively large number of countries. Second, some very unproductive banks exhibit commercial presences abroad.

These inconsistencies indicate the need for a model of international trade in financial services that accounts for additional sources of heterogeneity. In the banking industry, some natural candidates would be the risk preferences and risk-taking choices of banks.

\section{Acknowledgements}

This paper was partly written during visits of the authors to the Research Centre of the Deutsche Bundesbank and Sveriges Riksbank. Access to bank-level financial accounts and the External Position Report database of Bundesbank are gratefully acknowledged. We have benefited from comments on an earlier version received from seminars at the Bangor Business School, the University of Amsterdam, the University of Bonn, Deutsche Bundesbank, the 5th Macroeconomic Research Meeting (MaRem), and the CEPR-GIST conference held in Milano. Without implicating them, we are grateful to Yener Altunbas, Stefan Boes, Steven Brakman, Franziska Bremus, Jörg Breitung, Wouter den Haan, Harry Garretsen, John Goddard, Heinz Herrmann, Mathias Hoffmann, Jörn Kleinert, Thilo Liebig, Monika Merz, Phil Molyneux, Carola Munzert, Esteban Prieto, Ward Romp, Winfried Rudek, Jochen Schanz, Kevin Staub, John Thornton, Daniel Trefler, Neeltje van Horen, John Williams, and an anonymous referee for their feedback. Lena Tonzer provided efficient research assistance. Financial support from the National Science Foundation in the Netherlands (NWO) (M. Koetter), the Foundation "Stiftung Geld und Währung" (C. Koch), and the EFIGE project financed by the European Commission (SSH-2007-1.2.1) is gratefully acknowledged. All errors and inconsistencies are solely our own responsibility.

\section{References}

Basu, S., Wang, J.C., Fernald, J.G., 2008. A general-equilibrium, asset-pricing approach to the measurement of nominal and real bank output. In: Diewert, E., Greenlees, J. Hulten, C. (Eds.), Price Index Concepts and Measurement. University of Chicago Press, Chicago.
Bernard, A.B., Bradford, J.J., Redding, S., Schott, P., 2007. Firms in international trade. Journal of Economic Perspectives 21, 105-130.

Buch, C.M., Lipponer, A., 2007. FDI versus exports: evidence from German banks. Journal of Banking and Finance 31, 805-826.

Cerutti, E., Dell'Ariccia, G., Martínez Pería, M.S., 2007. How banks go abroad: branches or subsidiaries? Journal of Banking and Finance 31, 1669-1692.

Chen, N., Imbs, J., Scott, A., 2009. The dynamics of trade and competition. Journal of International Economics 77, 50-62.

De Loecker, J., 2007. Do exports generate higher productivity? Evidence from Slovenia Journal of International Economics 73, 69-98

Degryse, H., Ongena, S., 2005. Distance, lending relationships, and competition. Journal of Finance 60, 231-266.

Eaton, J., Kortum, S., Kramarz, F., 2004. Dissecting trade: firms, industries, and export destinations. American Economic Review 94, 150-154.

Epifaniy, P., Ganciaz, G., 2010. Trade, markup heterogeneity and misallocations. Journal of International Economics 83, 1-13.

Fiorentino, E., Koch, C.T., Rudek, W., 2010. Microdatabase: external position reports of German banks. Technical Report Deutsche Bundesbank. Frankfurt a.M.

Helpman, E., Melitz, M.J., Yeaple, S., 2004. Exports versus FDI with heterogeneous firms. American Economic Review 94, 300-316.

Helpman, E., Melitz, M.J., Rubinstein, Y., 2008. Estimating trade flows: trading partners and trading volumes. Quarterly Journal of Economics 123, 441-487.

Ishikawa, J., Morita, H., Mukoni, H., 2010. FDI in post-production services and product market competition. Journal of International Economics 82, 73-84.

Koetter, M., Wedow, M., 2010. Finance and growth in a bank-based economy: Is it quantity or quality that matters? Journal of International Money and Finance 29, $1529-1545$.

Koetter, M., Kolari, J.K., Spierdijk, L., Forthcoming. Enjoying the quiet life under deregulation? Evidence from adjusted Lerner indices for U.S. banks. Review of Economics and Statistics.

Konan, D.E., Maskus, K.E., 2006. Quantifying the impact of service liberalization in a developing country. Journal of Development Economics 81, 142-162.

Levinsohn, J., Petrin, A., 2003. Estimating production functions using inputs to control for unobservables. Review of Economic Studies 70, 317-341.

Lileeva, A., Trefler, D., 2010. Improved access to foreign markets raises plant-leve productivity ... for some plants. Quarterly Journal of Economics 125, 1051-1099.

Martin, R., 2008. Productivity dispersion, competition, and productivity measurement CEP Discussion Paper 692 London School of Economics, London.

Mayer, T., Ottaviano, G., 2007. The happy few: the internationalisation of European firms. Bruegel Blueprints 12 (4) Brussels.

Melitz, M.J., 2003. The impact of trade on intra-industry reallocations and aggregate industry productivity. Econometrica 71, 1695-1725.

van Biesebroeck, J., 2005. Exporting raises productivity in sub-Saharan African manufacturing firms. Journal of International Economics 67, 373-391.

Wong, C.Y.P., Wu, J., Zhang, A., 2006. A model of trade liberalization in services. Review of International Economics 14, 148-168.

WTO, 2009. International trade statistics 2009. World Trade Organization, Geneva. 